\title{
Plasma Adrenomedullin Levels in Patients with Non-Insulin Dependent Diabetes Mellitus: Close Relationships with Diabetic Complications
}

\author{
TOMOATSU NAKAMURA, KaZUfumi HONDA, SAN-E ISHIKAWA, KaZUO KITAMURA*, \\ TANENAO ETO*, AND TOSHIKAZU SAITO \\ Division of Endocrinology and Metabolism, Department of Medicine, Jichi Medical School, Tochigi 329-04 and \\ *Department of Medicine, Miyazaki Medical College, Miyazaki 889-16, Japan
}

\begin{abstract}
The present study was undertaken to determine plasma adrenomedullin levels in patients with non-insulin dependent diabetes mellitus (NIDDM) to elucidate the potential involvement in the pathogenesis of diabetic complications. The patients were 24 males and 21 females with ages of $55 \pm 2.1$ years (mean \pm SEM). Plasma adrenomedullin levels were $5.94 \pm 0.44 \mathrm{pmol} / l$ in patients with NIDDM, and were not affected by plasma glucose concentration. The plasma adrenomedullin increased dependent on the severity of diabetic nephropathy and retinopathy. Plasma levels of adrenomedullin positively correlated with various parameters, including serum creatinine levels, urinary excretion of protein, and systolic blood pressure. In contrast, there were negative correlations between the coefficient variation (CV) of RR intervals and plasma adrenomedullin, and between the conduction velocity of ulnar nerves and plasma adrenomedullin levels. These results indicate that the increase in plasma adrenomedullin was closely related to diabetic complications, which may be dependent on the development of microangiopathy.
\end{abstract}

Key words: Adrenomedullin, Diabetic complication, Non-insulin dependent diabetes mellitus (NIDDM)

(Endocrine Journal 45: 241-246, 1998)

\begin{abstract}
ADRENOMEDULLIN is a novel hypotensive peptide, which has been isolated from the acid extract of human pheochromocytoma [1]. The peptide consisting of 52 amino acids has an intracellular disulfide bond and shows a weak homology with calcitonin gene-related peptide (CGRP). Adrenomedullin has been found in various tissues, including vascular smooth muscles, kidneys, cardiac tissues and lungs [2, 3]. Previous studies reported that the plasma concentration of adrenomedullin increases in patients with

Received: June 2, 1997

Accepted: November 11, 1997

Correspondence to: Dr. Tomoatsu NAKAMURA, Division of Endocrinology and Metabolism, Department of Medicine, Jichi Medical School, 3311-1 Yakushiji, Minamikawachi-machi, Tochigi 329-04, Japan
\end{abstract}

hypertension, renal failure and congestive heart failure [4,5], though the major source of circulating adrenomedullin is unknown. Adrenomedullin has vasodilator and antiproliferative actions in vascular smooth muscle and glomerular mesangium [6, 7], as a paracrine or autocrine mechanism [8]. Diabetes mellitus has chronic complications, including retinopathy, neuropathy and nephropathy, which are closely related to microangiopathy $[9,10]$. These observations led us to speculate that adrenomedullin may play a role in diabetics.

The present study was undertaken to determine plasma adrenomedullin levels in patients with noninsulin dependent diabetes mellitus (NIDDM) to elucidate the potential involvement in the pathogenesis of diabetic complications. 


\section{Subjects and Methods}

\section{Subjects}

Forty-five patients with NIDDM were examined. They were 24 males and 21 females with ages ranging from 26 to 87 years ( $55 \pm 2.1$ years, mean \pm SEM). They were diagnosed as having NIDDM, based on their typical clinical courses and urinary C-peptide excretion $(71.5 \pm 9.5 \mu \mathrm{g} /$ day $)$. All the patients were admitted to Jichi Medical School Hospital to control their diabetic conditions. On admission, their blood glucose level was $12.2 \pm 0.9$ $\mathrm{mmol} / l$, hemoglobin $\mathrm{A}_{1 \mathrm{c}}\left(\mathrm{HbA}_{1 \mathrm{c}}\right)$ was $9.4 \pm 0.4 \%$, and their body mass index was $23.0 \pm 0.5 \mathrm{~kg} / \mathrm{m}^{2}$. Ten patients were treated with diet therapy, 21 with sulfonylurea and 14 with insulin therapy. The present study was carried out between May and July, 1995. Diabetic complications, including retinopathy, neuropathy and nephropathy were determined as below. The disorder of ocular fundi was examined by ophthalmologists using retinal camera and divided into 3 groups. To evaluate the disturbance of peripheral nerves, the conduction velocity of left ulnar nerves was measured with a Neuropack 8 (Nihon Kohden, Tokyo). The RR interval was measured supine position and expressed as the coefficient variation $(\mathrm{CV})$ to determine autonomic nerve function. Renal function was determined by serum levels of creatinine and urinary excretion of protein.

On day 2 or 3 of hospitalization, antecubital venous blood was taken at $0800 \mathrm{~h}$ after an overnight fast and a supine rest to measure plasma glucose, $\mathrm{HbA}_{1 \mathrm{c}}$, serum creatinine, plasma adrenomedullin, epinephrine, norepinephrine, arginine vasopressin (AVP) and renin activity (PRA). Blood pressure was measured at that time. Twenty-four hour urine collections were made for 3 days to determine excretion of C-peptide and protein. Urinary excretion of albumin was measured in patients who had no proteinuria in a qualitative test. In addition, a few days before the discharge, plasma adrenomedullin and glucose were measured in 40 patients.

\section{Hormonal assays}

Blood was collected into chilled tubes containing
EDTA-Na 2 ( $1 \mathrm{mg}$ per $\mathrm{m} l$ blood) and aprotinin (500 kallikrein-inhibitory units per $\mathrm{m} l$ blood) to measure plasma adrenomedullin and blood was collected into chilled tubes containing EDTA-Na 2 ( $1 \mathrm{mg}$ per $\mathrm{ml}$ blood) to measure plasma catecholamine, AVP and PRA. Plasma adrenomedullin was measured as described previously by Kitamura $\mathrm{K}$ et al. [11]. In brief, $2 \mathrm{ml}$ of plasma was applied to a conditioned Sep-Pak C18 cartridge (MilliporeWaters, Milford, MA), and the column was sequentially washed with $5 \mathrm{ml}$ of isotonic saline and $3 \mathrm{ml}$ of $20 \%$ acetonitril supplemented with $0.1 \%$ trifluoroacetic acid (TFA). The absorbed substances were eluted with $4 \mathrm{ml}$ of $50 \%$ acetonitril containing $0.1 \%$ TFA. The elute was lyophilized and dissolved in the assay buffer before use. Adrenomedullin was measured by RIA using double antibody method. The minimal detectable quantity of adrenomedullin was $1 \mathrm{fmol} /$ tube. The intra- and inter-assay coefficients of variation were $6 \%$ and $9 \%$, respectively. Plasma epinephrine and norepinephrine were measured with the automatic analyzer using HPLC system (HLC-725CA ; Tosoh, Tokyo). AVP was measured by RIA using AVP RIA kits (Mitsubishi Chemistry, Tokyo) [12]. Urinary C-peptide was measured by RIA using Cpeptide RIA kits (Daiichi Radioisotope, Tokyo). PRA was measured by RIA using PRA RIA kits (Tohle Fuji Bionics, Tokyo). Plasma adrenomedullin level in the age matched control group are $3.63 \pm 0.53 \mathrm{pmol} / l$, ranging from 1.88 to 4.52 $\mathrm{pmol} / \mathrm{l}$; epinephrine, $<550 \mathrm{pmol} / \mathrm{l}$; norepinephrine, $0.59-2.66 \mathrm{nmol} / l$; plasma AVP, $0.3-3.5 \mathrm{pmol} / l$; PRA, 0.08-0.81 ng/L/s; $\mathrm{HbA}_{1 \mathrm{c}}, 3.8-5.3 \%$; urinary excretion of C-peptide, $16-120 \mu \mathrm{g} /$ day; and urinary excretion of albumin, $<15 \mu \mathrm{g} / \mathrm{min}$.

\section{Statistical analysis}

All the data were expressed as the mean \pm SEM. All values were compared by one-way analysis of variance (ANOVA) and Fisher's $t$-test. The relationships between the variables were assessed by linear regression analysis. Comparison of plasma glucose and adrenomedullin levels on admission and discharge were analyzed by Student's paired $t$-test. Multiple regression analysis was used to determine plasma adrenomedullin levels. A $P$ value less than 0.05 was considered significant. 


\section{Results}

Plasma adrenomedullin levels were $5.94 \pm 0.44$ $\mathrm{pmol} / \mathrm{l}(\mathrm{n}=45)$, ranging from 1.88 to $14.51 \mathrm{pmol} / \mathrm{l}$ in the patients with NIDDM under uncontrolled diabetic conditions. Improvement of plasma glucose levels did not affect the plasma levels of adrenomedullin. Plasma glucose levels decreased from $12.2 \pm 0.9$ to $6.7 \pm 0.3 \mathrm{mmol} / l$ during the hospitalization, but plasma levels of adrenomedullin were $5.94 \pm 0.44$ and $6.23 \pm 0.53 \mathrm{pmol} / \mathrm{l}$ at the admission and the discharge, respectively.

Plasma adrenomedullin levels were classified with reference to diabetic nephropathy (Fig. 1). The patients were divided into three groups; no nephropathy, moderate nephropathy and chronic renal failure, which were based on the serum creatinine level and proteinuria. In the group of patients without nephropathy, urinary excretion of albumin did not exceed $15 \mu \mathrm{g} / \mathrm{min}$. They included 22 patients with the age of $55 \pm 2.9$ years and the BMI of $22.3 \pm 0.7 \mathrm{~kg} / \mathrm{m}^{2}$, and the duration of the disease was $8.7 \pm 1.4$ years. In the group of patients with moderate nephropathy, serum creatinine levels were less than $200 \mu \mathrm{mol} / l$ and urinary excretion of albumin exceeded $15 \mu \mathrm{g} / \mathrm{min}$. This group included 20 patients with the age of $53 \pm 3.3$ years and the BMI of $23.9 \pm 0.9 \mathrm{~kg} / \mathrm{m}^{2}$, and the duration of the disease was $13.8 \pm 1.6$ years. Serum creatinine levels

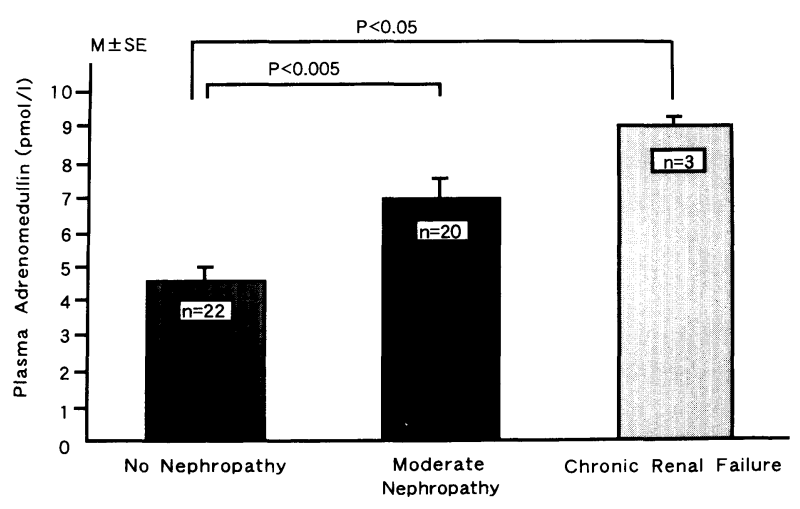

Fig. 1. Plasma adrenomedullin concentrations in patients with diabetic nephropathy. The patients with moderate nephropathy had serum creatinine levels less than $200 \mu \mathrm{mol} / l$ and urinary excretion of albumin greater than $15 \mu \mathrm{g} / \mathrm{min}$. The patients with chronic renal failure had serum creatinine levels more than $200 \mu \mathrm{mol} / l$. Analysis of variance resulted in a $F$ value of $5.92, P<0.01$. were more than $200 \mu \mathrm{mol} / l$ in the group of 3 patients with chronic renal failure, whose ages were $61 \pm 4.5$ years, the BMI of $22.0 \pm 0.6 \mathrm{~kg} / \mathrm{m}^{2}$, and the duration of the disease was $10.0 \pm 4.6$ years. As shown in Fig. 1, plasma adrenomedullin levels were much higher in the patients with nephropathy than in those without nephropathy. The increase was dependent on the severity of diabetic nephropathy.

Figure 2 shows the comparison of plasma adrenomedullin levels in 3 groups of diabetic patients with or without retinopathy. The patients were divided into 3 groups dependent upon the severity of retinal disturbance. A group of patients without retinopathy included 16 patients with the age of $51 \pm 3.8$ years, whose duration of disease was $7.2 \pm 1.5$ years. A group of patients with overt retinopathy, defined as having the stage of pre- or proliferative retinopathy, included 14 patients with the age of $54 \pm 2.5$ years and the duration of disease of $14.1 \pm 2.2$ years. The third group of patients with simple retinopathy included 15 patients with the age of $61 \pm 3.6$ years, whose duration of disease was $13.1 \pm 1.5$ years. Plasma adrenomedullin levels were $7.41 \pm 0.96 \mathrm{pmol} / l$ in the group of patients with overt retinopathy, a value significantly greater than that in the group without retinopathy.

Table 1 shows the correlations between plasma adrenomedullin levels and other variables. Plasma adrenomedullin levels were positively correlated with systolic blood pressure, serum creatinine levels and urinary excretion of protein. Significant negative relationships were found between plasma adrenomedullin levels and the glomerular filtration rate, between plasma adrenomedullin levels and

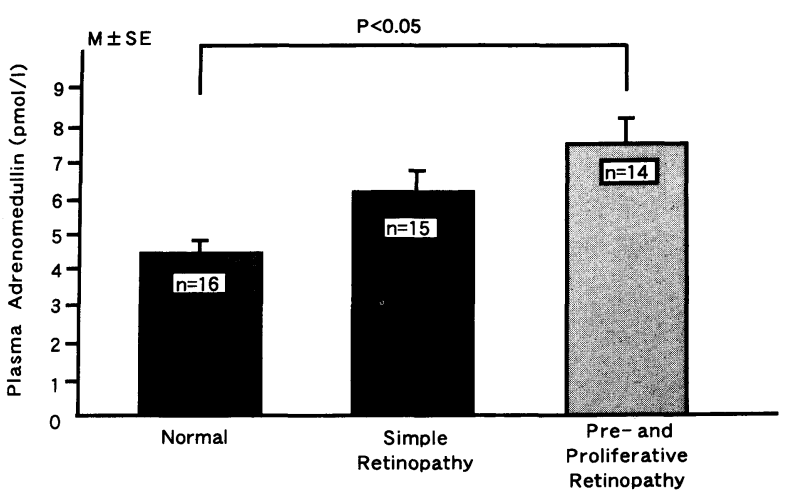

Fig. 2. Plasma adrenomedullin concentrations in patients with diabetic retinopathy. Analysis of variance resulted in a $F$ value of $4.71, P<0.05$. 
Table 1. Correlations between plasma adrenomedullin and other variables

\begin{tabular}{lcc}
\hline Parameters & $\begin{array}{c}\text { Correlation } \\
\text { coefficient (r) }\end{array}$ & $P$ Value \\
\hline Systolic blood pressure & 0.340 & $<0.005$ \\
Diastolic blood pressure & 0.236 & $\mathrm{NS}$ \\
Serum creatinine & 0.436 & $<0.005$ \\
Glomerular filtrate rate & -0.351 & $<0.02$ \\
Urinary excretion of protein & 0.531 & $<0.001$ \\
Hemoglobin Alc & -0.074 & $\mathrm{NS}$ \\
Urinary excretion of C-peptide & -0.114 & $\mathrm{NS}$ \\
Plasma epinephrine & -0.231 & $\mathrm{NS}$ \\
Plasma norepinephrine & 0.331 & $<0.05$ \\
Plasma renin activity & -0.054 & $\mathrm{NS}$ \\
Plasma arginine vasopressin & 0.275 & $\mathrm{NS}$ \\
CV of RR interval & -0.505 & $<0.001$ \\
Conduction velocity of ulnar sensory nerve & -0.396 & $<0.01$ \\
Conduction velocity of ulnar motor nerve & -0.349 & $<0.05$ \\
\hline
\end{tabular}

Table 2. Multiple regression analysis with plasma adrenomedullin as dependent variables

\begin{tabular}{lccc}
\hline Independent variable & $\begin{array}{c}\text { Parameter } \\
\text { estimate }\end{array}$ & S.E. & $P$ Value \\
\hline Intercept & 10.57 & 4.469 & 0.023 \\
Urinary excretion of protein & 0.586 & 0.249 & 0.024 \\
CV of RR interval & -0.919 & 0.454 & 0.049 \\
Conduction velocity of ulnar sensory nerve & -0.940 & 0.068 & 0.171 \\
Diabetic retinopathy (yes=1/no=0) & 0.575 & 0.769 & 0.459 \\
Systolic blood pressure & 0.008 & 0.020 & 0.707 \\
\hline
\end{tabular}

$r^{2}=0.463$; S.E.: standard error of parameter estimate.

the CV of $R R$ interval and between plasma adrenomedullin and the conduction velocity of both motor and sensory nerves of the left ulnar nerve. There was a weak correlation between plasma concentrations of adrenomedullin and norepinephrine. Plasma levels of adrenomedullin did not correlate with plasma levels of epinephrine, AVP, PRA, $\mathrm{HbA}_{1 \mathrm{c}}$ and urinary excretion of Cpeptide.

Multiple regression analysis revealed that the $\mathrm{CV}$ of $R R$ interval and urinary excretion of protein contributed to the determinants of plasma adrenomedullin levels $\left(\mathrm{r}^{2}=0.463, P<0.0001\right)$. The conduction velocity of the sensory nerve of the left ulnar nerve, diabetic retinopathy and systolic blood pressure were excluded from determinants (Table 2).

\section{Discussion}

The present study demonstrated plasma adrenomedullin levels in diabetic patients. Improvement of blood glucose control did not affect plasma levels of adrenomedullin. Plasma adrenomedullin levels had close correlation with the severity of diabetic complications, including nephropathy, retinopathy and neuropathy. Also, the increase was closely related to hypertension and the increase in plasma norepinephrine. The patients were divided into three groups, dependent on serum creatinine levels and proteinuria, as shown in Fig. 1. Also, the plasma level of adrenomedullin were negatively correlated with the glomerular filtration rate. We analyzed the relation of diabetic nephropathy to blood pressure. There was a positive correlation between systolic 
blood pressure and serum creatinine levels $(P<0.005)$. The co-existence of hypertension may play a role in the elevation of plasma adrenomedullin. Previous study reported a close relationships of plasma adrenomedullin with hypertension and renal failure [5]. Another possible factor is the reduced renal clearance of adrenomedullin [13]. However, this may be not the case, because recent study showed that pulmonary circulation may be one of the major sites of adrenomedullin clearance, and renal clearance might not [14]. Nevertheless, the precise mechanism of the metabolism of adrenomedullin remains undetermined.

We obtained further correlation of plasma adrenomedullin levels with diabetic retinopathy and neuropathy in the present study. They seem likely to be closely associated with hypertension. However, when we analyzed the patients in a different way, there was no positive correlation between the severity of diabetic retinopathy and systolic blood pressure $(P=0.482)$. In the case of diabetic neuropathy, the plasma adrenomedullin levels had a negative correlation with the conduction velocity of ulnar nerves and the $\mathrm{CV}$ of RR interval. Also, the significant relationship of the CV of RR interval with plasma adrenomedullin was obtained by multiple regression analysis. In order to assess the direct correlation between plasma adrenomedullin levels and diabetic complications, we reanalyzed 16 patients aged 55 \pm 1.3 years (mean \pm SEM) ranging from 48 to 61 years who had no hypertension and no renal dysfunction. They had never been diagnosed as hypertension during ambulatory care and their blood pressure did not exceed $140 / 85 \mathrm{mmHg}$ on admission. Their serum creatinine levels were less than $90 \mu \mathrm{mol} / l$. There was still a negative relationship between plasma adrenomedullin levels and the CV of RR interval in the 16 patients $(P<0.05$, $\mathrm{r}=0.51$ ). Therefore, we suggested that the autonomic neuropathy is an independent factor for elevating plasma adrenomedullin levels. We have studied the effect of sympathetic nervous system on plasma adrenomedullin levels in normal subjects and diabetic patients with orthostatic hypotension [15]. The maneuver of head-up tilt produced a significant reduction in plasma adrenomedullin. In contrast, plasma adrenomedullin levels were high in the diabetic patients with orthostatic hypotension, and remained unchanged following the head-up tilt. These observations indicate that the sympathetic nervous system is of great value in regulating adrenomedullin secretion.

It was originally reported that adrenomedullin was extracted from human pheochromocytoma tissues [1]. Recent studies clarified that adrenomedullin is synthesized in various tissues, including vascular smooth muscles, glomerular mesangium, cardiac tissues and lungs $[2,3,16]$. Adrenomedullin has vasodilator and antiproliferative effects in vascular smooth muscle cells and mesangial cells $[2,7]$. These effects are obtained as a paracrine or autocrine mechanism $[8,17,18]$. In the present study, the elevation of plasma adrenomedullin levels were closely associated with the diabetic complications, and not solely dependent on hypertension. The disturbance of diabetic complications is based on microangiopathy. Vascular bed damage may be originated by chronically stimulated high glucose and advanced glycosylated end product, which might be mediated through cytokines, including TGF $\beta$ and oxidized stress like oxidized low density lipoprotein [19]. Such mechanical and humoral factors may be involved in the enhanced production of adrenomedullin. The present study may therefore indicate that the elevated adrenomedullin in plasma is derived from vascular beds, dependent on the development of microangiopathy, and plays a certain role in protection against microvascular disturbance in diabetic patients.

\section{References}

1. Kitamura $K$, Kangawa $K$, Kawamoto M, Ichiki $Y$, Nakamura S, Matsuo H, Eto T (1993) Adrenomedullin: A novel hypotensive peptide isolated from human pheochromocytoma. Biochem Biophys Res Commun 192: 553-560.

2. Sakata J, Shimokubo T, Kitamura K, Nishizono M,
Iehiki Y, Kangawa K, Matsuo H, Eto T (1994) Distribution and characterization of immunoreactive rat adrenomedullin in tissue and plasma. FEBS Lett 352: 105-108.

3. Jougasaki $M$, Rodeheffer RJ, Redfield MM, Yamamoto K, Wei CM, McKinley LJ, Burnett JC Jr 
(1996) Cardiac secretion of adrenomedullin in human heart failure. J Clin Invest 97: 2370-2376.

4. Kato J, Kobayashi K, Etoh T, Tanaka M, Kitamura K, Imamura T, Koiwaya Y, Kangawa K, Eto T (1996) Plasma adrenomedullin concentration in patients with heart failure. J Clin Endocrinol Metab 81: 180183.

5. Ishimitsu T, Nishikimi T, Saito $Y$, Kitamura K, Eto T, Kangawa K, Matsuo H, Omae T, Matsuoka H (1994) Plasma levels of adrenomedullin, a newly identified hypotensive peptide, in patients with hypertension and renal failure. J Clin Invest 94: 21582161.

6. Kusaka I, Ishikawa S, Fujita N, Higashiyama M, Honda K, Okada K, Saito T (1996) Inhibition by adrenomedullin of arginine vasopressin-activated mitogen-activated protein kinase in rat glomerular mesangial cells via cAMP production. Hypertens Res 19: 113-119.

7. Horio T, Kohno M, Kano H, Ikeda M, Yasunari K, Yokokawa K, Minami M, Takeda T (1995) Adrenomedullin as a novel antimigration factor of vascular smooth muscle cells. Circ Res 77: 660-664.

8. Kato J, Kitamura K, Kangawa K, Eto T (1995) Receptors for adrenomedullin in human vascular endothelial cells. Eur J Pharmacol 289: 383-385.

9. Derubertis FR, Craven PA (1994) Activation of protein kinase $\mathrm{C}$ in glomerular cells in diabetes. Diabetes 43: 1-8.

10. Greene DA, Lattimer SA, Sima AAF (1988) Are disturbances of sorbitol, phosphoinositide, and $\mathrm{Na}^{+-}$ $\mathrm{K}+$-ATPase regulation involved in pathogenesis of diabetic neuropathy? Diabetes 37: 688-693.

11. Kitamura K, Ichiki Y, Tanaka M, Kawamoto M, Emura J, Sakakibara S, Kangawa K, Matsuo H, Eto $\mathrm{T}$ (1994) Immunoreactive adrenomedullin in human plasma. FFBS Lett 341: 288-290.

12. Ishikawa $S$, Saito $T$, Okada $K$, Tsutsui $T$, Kuzuya $T$ (1986) Effect of vasopressin antagonist on water excretion in inferior vena cava constriction. Kidney Int 30: 49-55.

13. Melick RA, Martin TJ (1969) Parathyroid hormone metabolism in man. Effect of nephrectomy. Clin Sci 37: 667-674.

14. Nishikimi T, Kitamura T, Saito $Y$, Shimada $K$, Ishimitsu T, Takamiya M, Kangawa $K$, Matsuo $H$, Eto T, Omae T (1994) Clinical studies on the sites of production and clearance of circulating adrenomedullin in human subjects. Hypertension 24: 600-604.

15. Nakamura $T$, Ishikawa $S$, Ideno J, Honda $K$, Rokkaku K, Nagasaka S, Kitamura K, Saito T (1997) Plasma adrenomedullin levels in patients with noninsulin dependent diabetes mellitus (NIDDM): Close relationship with diabetic complications. 79th annual meeting of the Endocrine Society, Minneapolis, USA, 480 (Abstract).

16. Minamino N, Shoji H, Sugo S, Kangawa K, Matsuo $\mathrm{H}$ (1995) Adrenocortical steroids, thyroid hormones and retinoic acid augment the production of adrenomedullin in vascular smooth muscle cells. Biochem Biophys Res Commun 211: 686-693.

17. Eguchi S, Hirata Y, Kano H, Sato K, Watanabe Y, Watanabe TX, Nakajima K, Sakakibara S, Marumo F (1994) Specific receptors for adrenomedullin in cultured rat vascular smooth muscle cells. FEBS Lett 340: 226-230.

18. Sugo S, Minamino N, Shoji H, Kanagawa K, Kitamura K, Eto T, Matsuo H (1994) Production and secretion of adrenomedullin from vascular smooth muscle cells: Augmented production by tumor necrosis factor-alpha. Biochem Biophys Res Commun 203: 719-726.

19. Sharma K, Ziyadeh FN (1995) Hyperglycemia and diabetic kidney disease. The case for transforming growth factor-beta as a key mediator. Diabetes 44 : 1139-1146. 